CAS 2016/A/4708, Belarus Canoe Association and Belarusian Senior Men's Canoe and Kayak Team Members $v$ International Canoe Federation, Award of 23 January 2017

\title{
Doping and Human Rights in Pariah States
}

\section{David McArdle*}

\section{Keywords}

Doping - tribunals - independence - Belarus - human rights

\begin{abstract}
On first reading, case 2016/A/4708 Belarus Canoe Association and Belarusian Senior Men's Canoe and Kayak Team Members v International Canoe Federation, award of 23 January 2017 (hereafter $B C A \cup I C F$ ) raises three familiar, deceptively simple, themes in anti-doping. Namely, the potential role of national criminal authorities in doping investigations; the relationship between those authorities and international sporting stakeholders; and the importance of those stakeholders adhering to their own rules when pursuing apparent antidoping allegations.
\end{abstract}

This paper addresses those aspects in detail, but the case has a significance that goes beyond anti-doping. Specifically, $B C A \vee I C F$ raises wider issues about anti-doping actors whose obligations under the WADA regime cannot be easily reconciled with their reliance on governments that use sports as a tool for cronyism and furthering political agendas. Such is the case in Belarus, where the relationship between a supposedly independent national antidoping authority and an ignoble and unhappy regime appears uncomfortably close. These concerns are compounded by sports federations who are only too happy to let Europe's last dictatorship host their international events.

\section{Facts and Procedure of the Case}

On 12 April 2016, French police and customs officials raided the training camp of the Belarus Canoe and Kayak team at Le Temple-sur-Lot, some 130km south-east of Bordeaux. Various substances, medications and materials that could be used for blood transfusions were

${ }^{*}$ Head of the School of Law, Stirling University, Scotland

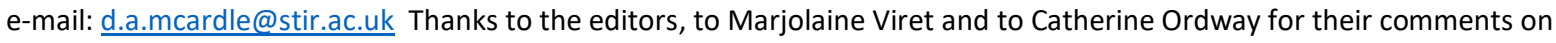
an earlier draft, but the errors are mine alone. 
confiscated, along with 16 capsules of Mildronate (a brand name for meldonium) which were found in the room of the head coach of the women's kayak team. Seventeen athletes underwent doping controls and five of the men's teams urine samples tested positive for meldonium - which is used principally in the treatment of angina and other heart diseases but which "has been used by athletes in order to avoid damage to their heart after intense sport exercise."1 The French authorities did not pursue the matter, choosing instead to pass their findings to the authorities in Belarus. On 15 June, the Belarus Canoe Association (BCA) notified the International Canoe Federation (ICF) that the positive tests for meldonium were to be treated as anti-doping rule violations (hereafter ADRVs), and the national anti-doping organisation (hereafter the NADO) had been notified of this in accordance with Article 14.1.2 of the WADA code. However, the BCA went on to state:

Due to the fact that WADA issued a Notice to Stakeholders regarding meldonium as well as guidance regarding the results management process, NADO Belarus with assistance of the Belarus Canoe Association conduct(ed) its own investigation regarding...the meldonium cases. $^{2}$

The BCA further reported that "all five athletes had established they had used meldonium prior to 1 January 2016 ...the concentration of meldonium in four samples causing such preinvestigation anti-doping check is below $1000 \mathrm{ng} / \mathrm{ml}$, which means that results management may be stayed" in accordance with WADA's meldonium notice to stakeholders. ${ }^{3}$

The stakeholder notice (which is no longer valid) had been released by WADA on 13 April $2016,{ }^{4}$ the day after the raid by the French authorities. It provided that, in cases where an athlete who was tested after 1 March 2016 claimed to have used meldonium before 1 January 2016, a urinary concentration of below $1000 \mathrm{ng} / \mathrm{ml}$ could lead to a finding of no fault in the absence of evidence that it was used after that date.

On 11 July, the ICF wrote to the BCA referencing the June 30 letter and said the matter would be discussed at an emergency meeting of the ICF Executive Board in two days' time.

\footnotetext{
${ }^{1}$ CAS 2016/A/4708, Belarus Canoe Association and Belarusian Senior Men's Canoe and Kayak Team Members v International Canoe Federation, Award of 23 January 2017, para. 52. The challenges posed by meldonium use and its treatment under the WADA Code has been extensively covered and need not detain us here, but see WADC Commentary, Meldonium and Moral Fault: Five Lessons Learned from the Sharapova ITF Tribunal Decision, 10 June 2016. http://wadccommentary.com/2016/06/. Accessed 30 April 2019. See also WADC Commentary, The Significance of Maria Sharapova's Fault, 30 September 2016. http://wadc-commentary.com/sharapova cas/. Accessed 30 April 2019.

${ }^{2}$ Ibid.

${ }^{3}$ CAS 2016/A/4708, Belarus Canoe Association and Belarusian Senior Men's Canoe and Kayak Team Members v International Canoe Federation, Award of 23 January 2017, para. 7.

${ }^{4}$ WADA, Notice - Meldonium, 30 June 2016. https://www.wada-ama.org/sites/default/files/resources/files/2016-06-30meldonium notice.pdf. Accessed 30 April 2019.
} 
It noted that under ICF anti-doping rules misleading, hiding or being found to be in breach of those rules could lead to sanctions on athletes, federations or officials and the imposition of financial penalties. While accepting that athletes who returned values for meldonium under $1000 \mathrm{ng} / \mathrm{ml}$ would normally be regarded as 'clean' under the WADA notice, it emphasised that there was an exception "where other evidence could be applied to those cases." With that in mind, it said that the French criminal authorities had provided "concrete information and indications that your athletes and officials have offences regarding doping irregularities (and) misuse of medication," and advised that the ICF was now pursuing its own case regarding violations of the anti-doping rules. ${ }^{5}$ Put another way, the ICF believed the additional evidence provided by the French authorities meant the initial finding of 'no fault' was unsatisfactory and had to be reviewed.

The BCA was given 24 hours to respond, which it did robustly. In addition to raising general complaints about their treatment at the hands of the French, it noted that no subsequent action was taken by the criminal or anti-doping authorities, stated the coach who had the meldonium possessed it for his own purposes - to treat a longstanding heart condition - and said the transfusion equipment that was found in the raid was "intended for emergency use only."6 The BCA acknowledged that customs rules had been broken by its members transporting meldonium into France but said it would appeal to the CAS if the ICF's Executive Committee imposed sanctions. It also revealed that it had been in text contact with the ICF's Chief Executive prior to its emergency meeting. Upon hearing of the BCA's intention to appeal, he had stated that "with these threats you will be aware that we will request even stronger penalties should we win or find more evidence."7

On 15 July, the ICF Executive Committee said all the athletes' urine samples were consistent with meldonium being ingested after 1 January 2016 and that the possession of the meldonium tablets was an ADRV under Rule 2.6.2 of its anti-doping rules (possession of a prohibited substance or method). Possession of transfusion equipment and needles likewise amounted to a violation of Rule 2.6.2 and the possession of other substances, notably Actovegin (calf serum, which facilitates blood doping and under the WADA Code cannot be used as an intravenous infusion or injection of more than $100 \mathrm{ml}$ every 12 hours) and Cytoflavin (which is used in the treatment of concussion and 'mild' brain injury but is not

\footnotetext{
${ }^{5}$ CAS 2016/A/4708, Belarus Canoe Association and Belarusian Senior Men's Canoe and Kayak Team Members v International Canoe Federation, Award of 23 January 2017, para. 10.

${ }^{6}$ Ibid.

7 Ibid., para. 14.
} 
restricted at all), "indicate the intent or actual doping processes being carried out by these athletes." 8

Rather than sanction individuals, the Executive Committee imposed a one-year ban on the men's kayak and canoe teams in their entirety, ostensibly invoking Article 12.3 of the ICF anti-doping rules to take 'additional disciplinary action' on the ground that 4 or more ADRVs had occurred in a 12-month period. The teams' places at the Rio Olympics were withdrawn, mandatory anti-doping training and at least three doping tests of all athletes over a 12-month period were imposed. ${ }^{9}$ True to its word, the BCA appealed to the CAS and asked that the decision be stayed and the hearing expedited so that, if successful, their athletes could compete at Rio. In its haste the BCA made significant errors which culminated in that request being rejected "because the appellants referred only to the criterion of irreparable harm but not also to the criteria of the likelihood of success and of the balance of interest." ${ }^{\prime 10}$ Rule 37 of the 2016 CAS Code of Sports-Related Arbitration ${ }^{11}$ (which was the version in force at the time of the hearing) states that the panel chair "shall consider" all three of those elements in considering requests for provisional and conservatory measures. The BCA had thus erred by not addressing all three aspects and the request for a stay had been "clearly incomplete."12

The case was heard in November 2016, and it is immediately apparent that the ICF's handling of the matter was fundamentally flawed. An initial, although not ultimately fatal, difficulty was that Article 42 of the ICF Statutes defines the disciplinary measures that can be imposed by the Executive Committee - namely, caution, reprimand and exclusion of some or all members of a national federation from competition - while suspensions fall within the competence of the Board of Directors. ${ }^{13}$ While the ICF contended that a 'suspension' could be meaningfully distinguished from an 'exclusion', the BCA argued that the two were different and the Executive Committee did not have the competence to impose the former. Alternatively, if it did have competence the Executive Committee had acted ultra vires because the potential sanctions had not been clearly defined: they were not based on proper rules and regulations, they were not predictable and there was no clear connection between

\footnotetext{
8 Ibid., para. 15.

${ }^{9}$ lbid.

${ }^{10}$ Ibid., para. 20.

112016 CAS Code, available at https://www.tas-cas.org/fileadmin/user upload/Code 2016 final en .pdf. Accessed 30 April 2019. The same requirement existed in R37 of the 2017 CAS Code, and it remains in the current (2019) version: https://www.tas-cas.org/fileadmin/user upload/Code 2019 en .pdf. Accessed 30 April 2019.

12 Ibid., para. 81.

${ }^{13}$ Art. 42 ICF Statutes. https://federations.canoeicf.com/sites/default/files/icf_statutes_2015_with_changes.pdf. Accessed 30 April 2019.
} 
the behaviour and the sanction. ${ }^{14}$ Further, the BCA argued that the ICF could not impose 'additional' measures under Article 12.3 of the anti-doping rules because there had been no initial sanctions imposed under Articles 12.1 or $12.2 .{ }^{15}$ It also argued that the WADA Code and the ICF rules (which reflect the Code's terms) had been breached by the failures in the testing, analysis, investigation and results management processes and accordingly there had been no fair hearing. In fact, there had been no hearing at all because the whole process had been handled by the ICF secretary general and its lawyers rather than by a properlyconstituted anti-doping panel, and they had relied exclusively upon "vague information" provided by the French authorities. Nine of the athletes impacted by the team ban had not even been at the training camp, and the BCA said there were no grounds for sanctioning the team doctors, coaches and other members of the entourage. ${ }^{16}$

In response, the ICF said that Article 42 of its Statutes gave its Executive Committee the authority to render a decision and use of the word 'suspension' rather than 'exclusion' was not decisive; the focus should be "not on the words used but on the effect of the appealed decision." 17 The decision's consequence was not the blanket suspension of the BCA from all canoeing activities, but to prevent the senior men's canoe and kayak teams from participating in international events. This, said the ICF, is exactly what Article 42(c) envisaged, and "even if the rules may be improved they are understandable and clear on their face." 18 That being so, there was no need for the Executive Committee to impose disciplinary measures under Articles 12.1 (withholding funding) or 12.2 (reimbursement of costs) of the Anti-Doping rules before 'additional measures' could be applied under Article 12.3. It sufficed that its own hearing had determine that four or more offences had been committed over a 12-month period.

On that point, the ICF argued that "the mere presence of a prohibited substance is an antidoping violation" even though four of the five positive tests had apparently returned meldonium levels below the WADA threshold. It said the BCA's explanation that the

\footnotetext{
${ }^{14}$ CAS 2016/A/4708, Belarus Canoe Association and Belarusian Senior Men's Canoe and Kayak Team Members v International Canoe Federation, Award of 23 January 2017, para. 28.

${ }^{15}$ Article 12.3 of the Anti-Doping Rules provides (in salient part)

12.3 The ICF may elect to take additional disciplinary actions against national federations with respect to recognition, eligibility...and fines based on the following: 12.3.1 Four or more violations committed by athletes or other persons affiliated with a national federation within a twelve-month period in testing conducted by the ICF or anti-doping organisations other than the national federation or its national anti-doping organisation.

${ }^{16}$ CAS 2016/A/4708, Belarus Canoe Association and Belarusian Senior Men's Canoe and Kayak Team Members v International Canoe Federation, Award of 23 January 2017, para. 28.

17 Ibid., para. 30.

18 lbid.
} 
meldonium was for the personal use of a team coach was not credible "in view of so many athletes found with this substance at the training camp." Additionally, the fact that meldonium had been 'prescribed' by a team doctor with a background in paediatric medicine rather than by the coach's personal physician, the argument that Actovegin was for a female athlete who had recently been diagnosed with a myocardial dystrophy, and the assertion that the transfusion systems were for 'emergency use' were given short shrift. "The ICF considers it established that members of the BCA connected to the senior men's teams committed further anti-doping violations" in addition to the five positive tests. Article 12.3.1 had thus been properly applied by the Executive Committee, which "could have and might in future impose a suspension of the BCA's membership for up to four years." 19 The ICF acknowledged that the decision to impose 'additional sanctions' had not been preceded by the imposition of any sanctions on anyone, but it contended that there had been no violation of procedural rights because the French National Anti-Doping Organisation, not the ICF, had been responsible for testing and results management. Further, Article 12 of the Anti-Doping rules "does not grant any hearing or procedural rights to the athletes and their entourage," and "the athletes have not been punished as a direct consequence of their individual anti-doping violations, but because of their affiliation to the BCA's banned team." ${ }^{20}$ The fact that the BCA had admitted anti-doping violations on the part of individual athletes in its letter of 15 June was also significant in encouraging the Executive Committee to proceed, as was "the refusal of the BCA to acknowledge any (institutional) wrongdoing.",21

\section{The Decision}

The CAS had to consider two principal points. First, whether the ICF Executive Committee had been entitled to impose the 'suspension'; and second, if the answer to the first point was 'yes', whether the Executive Committee had violated its own rules and the procedural rights of the appellants in doing so.

On addressing the first point, the CAS confirmed that Article 12.3 of the ICF Anti-Doping Rules did not specify which body was entitled to impose the various potential sanctions. ${ }^{22}$ However, Article 42 of the ICF Statutes was clearer: exclusion of "some or all members of a national federation" from participation in competitions and the imposition of cautions,

\footnotetext{
${ }^{19} \mathrm{lbid}$.

${ }^{20} \mathrm{Ibid}$.

${ }^{21} \mathrm{lbid}$.

${ }^{22}$ Art. 12.3 ICF Anti-Doping Rules. https://www.canoeicf.com/sites/default/files/icf antidoping rules based upon the 2015 revised wada code 0.pdf. Accessed 30 April 2019.
} 
reprimands and fines were decisions of the Executive Committee; suspension was a decision of the Board of Directors while expulsion required a vote of two-thirds of the ICF Congress. ${ }^{23}$ The Panel agreed with the ICF that the one-year suspension of "the senior men's canoe and kayak teams including coaches, medical staff and entourage for all international competitions" was not actually a suspension but an exclusion:

A suspension may be decided by the ICF Board of Directors, a (partial) exclusion by the ICF Executive Committee...The Panel follows the arguments of the (ICF) in that the Executive Board erred in choosing the word 'suspension' but, in fact, wanted to apply and applied the measure of 'exclusion' and thus - in principle used the competence applied to it by Article 42 of the ICF Statutes. ${ }^{24}$

The decision to exclude had not erroneously referred to any of the grounds for 'suspension' laid down in Article 42.2, and in the absence of evidence to the contrary 'suspension' must be taken to have its generally-accepted meaning within sports federations - namely, that "use of all membership rights by the respective national federation or individual shall be prohibited for a certain period of time." 25 To that extent, the appellants were unsuccessful in arguing that the 'suspension' had been imposed by the wrong body.

But the Federation's difficulty with the second point proved insurmountable. To recap, Article 12.3 of the ICF Anti-Doping Rules established that it could only take 'additional' measures with respect to recognition, eligibility and fines if one of the four Article 12.3 subclauses were engaged. In this regard, the Federation contended that Article 12.3.1, the 'four offences in twelve months' clause, had been operational. However, the CAS pointed out that 12.3.1 requires "testing conducted by the ICF or anti-doping organisations other than the national federation or its national anti-doping organisation." There had been no testing in compliance with that requirement (in part for reasons explored below) and, taken together, the unsatisfactory establishing of the facts and the absence of an anti-doping decision rendered by a competent body meant the Executive Committee's decision had been "premature." ${ }^{26}$ In any event, exclusions under Article 12.3 could be imposed only against "all officials" of the national federation. The ICF could not use Article 12.3 as a means of

\footnotetext{
${ }^{23}$ CAS 2016/A/4708, Belarus Canoe Association and Belarusian Senior Men's Canoe and Kayak Team Members v International Canoe Federation, Award of 23 January 2017, paras 42-44.

${ }^{24}$ Ibid., para. 44.

25 Ibid., para. 45.

${ }^{26}$ Ibid., para. 48.
} 
sanctioning officials or athletes in some, but not all, disciplines which came under that federation's authority.

The Panels' comments on the 'unsatisfactory establishment of the facts' merit closer scrutiny. First, on the burden facing the ICF with respect of meldonium use, it stated as follows:

Having not been provided with evidence by the ICF to its comfortable satisfaction that the BCA athletes took meldonium after 1 January 2016, the Panel holds that there was no anti-doping rule violation as to meldonium. The reference to the WADA notice of 30 June does not exculpate the ICF from its obligation under Article 3.1 ICF ADR to demonstrate to the Panels' comfortable satisfaction...that the prohibited substance entered the body of the athletes after 1 January 2016.

In contrast, "the athletes fulfilled their obligation under Article 2.1.1. ICF ADR to make sure that no prohibited substance entered their body after 1 January 2016." ${ }^{27}$ However, purporting to place the burden on the athletes in this way cannot be reconciled with the WADA Notice, which allowed for no-fault findings "in the absence of evidence that meldonium was used after 1 January $2016^{\text {"28 }}$ but makes no comment about athletes bearing the burden. The case thus shows the difficulty in establishing to comfortable satisfaction that readings which were under the threshold were still a consequence of using meldonium after 1 January. That difficulty is also evident from the Panel's holding that that the failure to establish meldonium use after the cut-off date applied also to the one athlete whose meldonium levels were above the threshold. ${ }^{29}$

Perhaps the key factor in the Panel decision was the testimony of Professor Ivar Kalvins, the inventor of meldonium, who discussed the 'slow phase' of its excretion. The existence of a 'slow phase' further muddies the waters on meldonium use and prohibition because it "can last for many months as the body tries to recapture (the 'escaping' meldonium)" and the length of excretion can be increased depending on weight loss, food consumption, the length of meldonium use and so forth. ${ }^{30}$ The Panel also referred to a recent scientific study which suggested that "all athletes who showed any concentration of meldonium had a genetic mutation." While it was not persuaded by the argument that the Chernobyl disaster could

\footnotetext{
${ }^{27}$ Ibid., para. 54.

${ }^{28}$ WADA, Notice - Meldonium, 30 June 2016. https://www.wada-ama.org/sites/default/files/resources/files/2016-06-30meldonium_notice.pdf. Accessed 30 April 2019.

${ }^{29}$ CAS 2016/A/4708, Belarus Canoe Association and Belarusian Senior Men's Canoe and Kayak Team Members v International Canoe Federation, Award of 23 January 2017, para. 54.

30 Ibid., para. 52.
} 
have contributed to the athletes' excretion rates, it was satisfied that the ICF had failed to prove "the intake of meldonium by the five BCA athletes after January 2016."31

Neither was the Panel comfortably satisfied that the coach's assertion that he had the meldonium for his own use was a lie. He had advanced an argument of sorts for his possessing it, and "there is no obligation for a therapeutic use exemption for coaches under the WADA Code or the ICF ADR." ${ }^{32}$ So the sport's anti-doping rules had not been violated even though the explanation might strike a casual observer as improbable. The Panel also found the explanation that the 'transfusion kits' were for use in emergencies only and taken to training sessions but never to competitions was "plausible and consistent" although the French authorities had found over 230 syringes in the course of its investigation, ${ }^{33}$ so they were clearly planning for the possibility of a devastatingly widespread and immediate need for them. Again, the ICF had failed to establish to comfortable satisfaction that the kits served the aims of prohibited methods, however. "The fact that (other experts) did not see a need for an emergency kit and never used such kit does not convince the Panel that (the team doctor), bound to a different legislation and medical culture, possessed such equipment" for illegitimate medical use. ${ }^{34}$

The Panel then considered the ICF's contention that the mere presence of a prohibited substance in an athlete's body was an ADRV and there was no requirement for the Executive Committee to have first imposed sanctions under Article 12.1 or on individual athletes before it could utilise Article $12.3 .^{35}$ It said, unsurprisingly: ${ }^{36}$

The Panel finds that to follow such arguments would empty the competence of the ICF doping control panel, circumvent the system of distribution of powers laid down by the ICF Statutes and Anti-Doping Regulations and deprive the individual persons concerned of all procedural guarantees laid down by the WADA Code and implemented properly for the ICF by the ICF Anti-Doping Rules.

The role of an ICF doping control panel might become limited to rubber-stamping decisions taken by the Executive Committee, but it would also "lead to disaster" if a panel were to

\footnotetext{
31 Ibid., para. 53.

32 Ibid., para. 55.

33 Ibid., para. 57.

${ }^{34} \mathrm{Ibid} .$, para. 59. The Award actually speaks of "legitimate medical use" but it is clear from the context that 'legitimate' was used in error.

35 Ibid., para. 62.

36 lbid., para. 63.
} 
subsequently investigate and find there had been no individual ADRV after the Executive Committee had decided there was and had imposed sanctions.

The Panel's decision on the merits was entirely proper, but its opinion that the establishing of "independent judicial bodies" to replace political bodies deciding on ADRVs was "one of the essential achievements of the WADA Code" ${ }^{\$ 7}$ does not withstand scrutiny given the wider, political, issues of the case that are discussed below. Prior to the CAS' inception in 1984 and WADA's creation in 1999, appeals against sports' decisions on ADRVs usually fell within the jurisdiction of domestic civil courts, ${ }^{38}$ and this inevitably gave rise to challenges that have been widely-documented and led to proposals for reform. Indeed, the CAS website notes that "at the beginning of the 1980s, the regular increase in the number of international sportsrelated disputes and the absence of any independent authority specialising in sports-related problems and authorised to pronounce binding decisions led the top sports organisations to reflect on the question of sports dispute resolution." 39 CAS' creation was a response to the cost and complexity of litigation and the inevitability of different outcomes arising in different jurisdictions as a result of genuine "judicial bodies" carrying out their proper functions.

The case reminds us that sports dispute resolution is susceptible to political interference notwithstanding the undoubted benefits it brings because these entities are not truly 'independent' and there is the potential for improper influence. It was absolutely right that the appealed decision was "fully cancelled" 40 but the argument that these tribunals are "judicial bodies' should be approached with caution. The German Federal Court of Justice's ruling in DESG and ISU $v$ Pechstein ${ }^{41}$ is a useful explanation of why the CAS can be properly regarded as 'independent' and might be perceived as a 'judicial body.' But neither the CAS nor the international federations can have oversight of all the decisions taken by national antidoping bodies, and the wider sports law and policy community needs to be vigilant when confronted with decisions that seem tainted by political interference. $B C A \quad v I C F$ is a paradigm example of this because further investigation of Belarus' anti-doping apparatus confirms it is not independent of the state either in fact or in law. To the contrary, it is a tool

\footnotetext{
37 lbid., para. 65.

${ }^{38}$ See for example the English cases of Modahl v British Athletic Federation [2001] EWCA Civ 1447 (12 October 2001); Korda v International Tennis Federation, The Times (4 February 1999); Gasser v Stinson (1988) CH-88_G_2191.

${ }^{39}$ CAS, History of the CAS. http://www.tas-cas.org/en/general-information/history-of-the-cas.html. Accessed 30 April 2019.

${ }^{40}$ CAS 2016/A/4708, Belarus Canoe Association and Belarusian Senior Men's Canoe and Kayak Team Members v International Canoe Federation, Award of 23 January 2017, para. 81.

${ }^{41}$ Judgment of 7 June 2016, KZR 6/15, English translation available at https://www.tas-

cas.org/fileadmin/user upload/Pechstein ISU translation ENG final.pdf. Accessed 13 May 2019.
} 
of government which has the clear potential to serve wider the political aims of an oppressive regime rather than the goal of clean sport.

\section{State Actors, Convention Obligations and Anti-Doping}

In many, perhaps most, countries the anti-doping industry's reliance on state funds does not fatally compromise its integrity because it is sufficiently at arms' length from government and sufficiently transparent in its operations. Thus, it allows athletes and other stakeholders a high degree of confidence in its independence or, ${ }^{42}$ failing that, the opportunity to offer informed criticism about its links with the state should their de facto independence come into question. Other than funding the work of anti-doping actors, nation states' contributions derive not from the WADA Code directly but from national laws, which invariably have their origins in the two international anti-doping instruments, the Council of Europe Convention ${ }^{43}$ (which pre-dates the WADA Code) and the UNESCO Convention (which post-dates it). The nature and extent of state parties' legal obligation rests on whether those instruments' provisions have been incorporated into national law or otherwise form the basis of antidoping policy in accordance with Article 6 of the UNESCO Convention and Article 1 of the Council of Europe Convention.

In addition, states ratifying the Council of Europe Convention commit themselves to participating in the monitoring processes established by Articles 10 and 11. The national reports that are part of that monitoring process provide both a mechanism for scrutinising their independence and an insight into what is actually happening in those countries, representing an examination of 'law on the ground' as opposed to 'law in the books', to adopt the language of legal consciousness. ${ }^{44}$ They are particularly pertinent here because they show how concerns which pre-date the BCF case still have implications that go beyond the world of drugs and sports and ought not to be considered in isolation.

The Council of Europe Convention calls upon signatory states to "undertake, within the limits of their respective Constitutional provisions" $" 45$ the steps necessary to comply with it and to

\footnotetext{
42 Department of Culture, Media and Sport, Tailored Review of UK Anti-Doping, January 2018. https://assets.publishing.service.gov.uk/government/uploads/system/uploads/attachment_data/file/677496/Tailored_Rev iew_of_UK_Anti-Doping_-_Final_Version_for_Publication_.pdf; Philip Clemo, Funding, Independence and Effectiveness. Key Points from the Government's Tailored Review of Anti-Doping, 27 June 2018. https://www.lawinsport.com/topics/articles/item/funding-independence-and-effectiveness-key-points-from-thegovernment-s-tailored-review-of-uk-anti-doping. Accessed 30 April 2019.

${ }^{43}$ ETS 135, 16 November 1989; Ed 2005/Convention Anti-Doping Rev.

${ }^{44}$ Hertogh and Kurkchiyan 2016.
} 
"co-ordinate the policies and actions of their government departments and other public agencies concerned with combatting doping. ${ }^{46}$ France, the first state actor involved in this case, ratified the Convention in 1991 by means of the Ratification Act 19-1144 and has since passed a number of acts, decrees and implementing orders designed to give effect to it. The National Anti-Doping Agency is now the key authority. It is arms-length from government although dependent on it for funding, and there have always been important roles for state actors including the customs bodies and national police authorities. ${ }^{47}$ The raid at Le Templesur-Lot is a particularly robust example of a state having laws and policies that reflect its obligations under Article 4(1) to adopt measures to control the movement, possession, importation, distribution and sale of doping agents and methods - and of those instruments being accompanied by a political willingness to use them. Horta et al's Report into French compliance with the Convention explained how the French Public Health Code lays down extensive criminal sanctions for doping-related offences and gives various organs the authority to carry out raids to facilitate compliance. ${ }^{48}$ The Police Judicaire, acting under the authority of the Criminal Code, ordinarily carries out the role while overseen by a judicial authority, and "seizures may be made if authorisation is given by the President of the Regional Court or by a specially-delegated member of the court." ${ }^{\prime 49}$ This is precisely what happened with the Belarus paddle athletes.

It is also notable that Council of Europe Convention Article 8(2)(c) requests state parties "to initiate bilateral and multilateral co-operation between their appropriate agencies, authorities and organisations in order to achieve, at the international level as well, the purposes set out in Article 4.1." France and Belarus had signed a bilateral agreement in December $1995,{ }^{50}$ four years before WADA was created, and the global growth of such agreements around that time "constituted, in effect, public recognition by governments of both the ineffectiveness of IOC policy and the need for governments to introduce more effective anti-doping policy." 51 WADA has since commended bilateral agreements as part of "developed NADOs'...responsibility to assist NADOs in the process of their development" ${ }^{\text {"52 }}$ and its 2014 guidelines suggested that they could "generate a wide range of benefits including establishing

\footnotetext{
${ }^{46}$ ETS 135, 16 November 1989, Art. 1, 3.

47 Horta et al., Project on the Compliance with Commitments: Commitments by France with the Anti-Doping Convention, 26 August 2004. https://rm.coe.int/project-on-compliance-with-commitments-respect-by-france-of-the-antid/168073ac52. Accessed 30 April 2019.

48 Ibid., p 6.

49 Ibid., p 18.

50 Ibid., p 34.

${ }^{51}$ Hanstad and Houlihan 2015.

52 Ibid.
} 
international benchmarks for best practice, sharing solutions of practical issues, building antidoping competence and professionalism, improving quality management and improving information exchange... Suggested foci for collaboration include how to initiate cooperation with national sports organisations, how to establish a NADO and how to develop an annual doping control programme. ${ }^{, 53}$ Perhaps the French passed their evidence to the Belarusian authorities in this spirit of bilateralism and cooperation, or perhaps they did not think the time and resources required to pursue it was merited. Or maybe they simply wanted to emphasise that they possessed both the legal basis and the political will to raid other countries' training camps if they wished, without particularly caring what happened next.

At the end of their Report into French compliance, Horta et al concluded, "we must hope...that the signing of a global Convention under the auspices of UNESCO will lead to a more widespread use of the foundations laid by the Council of Europe Convention." ${ }^{54}$ That Convention, ${ }^{55}$ signed in October 2005, sought to "promote the prevention of and the fight against doping in sport, with a view to its elimination." ${ }^{56}$ As with the Council of Europe Convention, it requires state parties to "adopt appropriate measures at the national and international level" to encourage all forms of international cooperation aimed at protecting athletes and ethics, and to foster cooperation with WADA in particular. There are thus in place two international Conventions which have very similar provisions. Both have been signed and ratified by France and Belarus, both countries have been the subject of compliance reports under the Council of Europe Convention, and both countries participate in the biannual conference of parties to the UNESCO Convention. ${ }^{57}$ That is where the similarities end.

\section{Back in the USSR}

\footnotetext{
$53 \mathrm{lbid}$, discussing WADA/Anti-Doping Norway, International NADO Cooperation Projects: A Guideline with Templates for NADO-to-NADO Partnerships, 2014. https://onad-monaco.mc/wp-content/uploads/2015/09/WADA-GuidelinesInternational-NADO-Cooperation-EN.pdf. Accessed 30 April 2019.

54 Horta et al., Project on the Compliance with Commitments: Commitments by France with the Anti-Doping Convention, 26 August 2004. https://rm.coe.int/project-on-compliance-with-commitments-respect-by-france-of-the-antid/168073ac52. Accessed 30 April 2019.

55 UNESCO (2005) 'International Convention Against Doping in Sport' ED.2005/Convention Anti-Doping Rev Paris: UNESCO

${ }^{56}$ Ibid., Art. 1

${ }^{57}$ For the report on the 2017 Conference, see UNESCO, Conference of Parties to the International Convention Against Doping in Sport, 2017. http://unesdoc.unesco.org/images/0025/002599/259976E.pdf. Accessed 30 April 2019.
} 
The Monitoring Group for the Council of Europe Convention visited Belarus in November 2014, shortly after the country's new National Law on Physical Culture and Sports came into force, and its Report was submitted a year later. ${ }^{58}$

Signatory states are required to submit auto-evaluation report on compliance with the Convention prior to visits from the Monitoring Group. In compiling theirs, the authorities in Belarus said this new law was in conformity with the WADA Code and WADA international standards ${ }^{59}$ and said that the NADO "ensures all stages of doping control, except laboratory analysis and appeal review" ${ }^{60}$ as required under Article 3 of the Convention. On concluding its own inquiry, the Evaluation Team declared that Belarus was "only partially" fulfilling the political commitment expected under Article 1 because the national law did not define the obligations of government departments and public bodies with regard to anti-doping. It recommended reform so that "the obligations of the NADA, the country's sports organisations and the government departments and public bodies... be defined." It also called on Belarus to ratify the Additional Protocol on mutual recognition of doping controls, which in principle allows WADA to conduct out-of-competition tests in the signatories' territory although one imagines that very exceptional circumstances would have to arise before WADA is persuaded to use its limited resources to do this. In any event, Belarus ratified the Additional Protocol in December $2016^{61}$ and there was testing of its athletes' samples at accredited laboratories after June of that year in the run-up to the Rio Olympics, ${ }^{62}$ but the Evaluation Team had other reservations. These included the national law's over-broad definition of "athlete" as "any person getting sports training on a chosen sport" which created an "unduly heavy obligation" to control purely casual participants when the priority should be "on the (elite) level of sportsmen and sportswomen where doping is known to exist." ${ }^{\text {" It }}$ was especially concerned that the NADO was not at arm's length from the state but was clearly a governmental organisation, presciently noting that this "raises concerns about the independence of...its operations and decision-making processes" given that the NADO relied

\footnotetext{
${ }^{58}$ Council of Europe, Respect by Belarus of the Anti-Doping Convention, 12 November 2015. https://rm.coe.int/project-oncompliance-with-commitments-respect-by-belarus-of-the-anti-/168073acb6. Accessed 30 April 2019.

59 lbid., p 5.

60 Ibid., p 6.

61 Liam Morgan, Belarus Joins Signatories of Council of Europe's Additional Protocol to the Anti-Doping Convention, 10 December 2016. https://www.insidethegames.biz/articles/1044685/belarus-join-signatories-of-council-of-europesadditional-protocol-to-the-anti-doping-convention. Accessed 19 October 2018. Accessed 30 April 2019.

${ }^{62}$ Belarusian Athletes Tested At WADA-Accredited Laboratories Ahead of Rio, 27 June 2016. https://www.belarus.by/en/government/events/belarusian-olympians-tested-in-wada-accredited-laboratories-ahead-ofrio_i_0000042008.html. Accessed 30 April 2019.

${ }^{63}$ Council of Europe, Respect by Belarus of the Anti-Doping Convention, 12 November 2015. https://rm.coe.int/project-oncompliance-with-commitments-respect-by-belarus-of-the-anti-/168073acb6. p 17. Accessed 30 April 2019.
} 
exclusively on the state for the funding of testing, education and all other functions. It recommended that the NADO "should have sufficient budget and administrative/operational autonomy to conduct testing and its other core activities, and this should be reflected in, and secured by, legislation" which removed the possibility of government pressure and conflicts of interest. ${ }^{64}$ Perhaps matters have got worse since the Evaluation Team's visit, but in light of $B C A$ v ICF it cannot currently be regarded as 'independent.'

Other concerns about the state's role in anti-doping arose from the Evaluation Team's comments on the advanced state of Belarus' pharmaceutical industry and the government's links to it. It discovered that "currently, 28 pharmaceutical companies operate in Belarus, producing medicines for the Belarusian market and for export to many other countries, and the pharmaceutical industry is regulated by the Ministry of Health, which also has responsibility for overseeing the industry's work" ${ }^{65}$ as well as controlling anti-doping efforts. Co-operation between the pharmaceutical industry and anti-doping authorities is an important aspect of the Council of Europe's anti-doping strategy, ${ }^{66}$ but there was an implicit concern about the symbiotic relationship between the industry and government. Given what is known about individuals who have roles in the industry, government and sport (as explored below), the concern that this relationship might impact anti-doping activities is by no means fanciful. There were also considerable delays in the sharing of data between government agencies, customs and police authorities and the NADO, which seemed to be last in the queue for the receipt of information.

Lastly, although the NADO's draft 2015 rules allowed it and other anti-doping organisations to carry out reciprocal testing of athletes within their jurisdiction, "there are no official agreements in place between the Belarusian authorities or the sport organisations of Belarus and other national anti-doping organisations or international federations for the testing of athletes from Belarus when training in other countries." 67 The Evaluation Team said that those draft rules could not come into force until WADA had approved them, so the 2014 rules had to remain in force and these were not WADA compliant because they did not meet

\footnotetext{
64 Ibid., pp 19- 20.

65 Ibid., p 20.

${ }^{66}$ Gabriella Battaini-Dragoni, Introductory Remarks at 'The Pharmaceutical Industry and the Fight against Doping' International Conference, 12 September 2012. https://www.wadaama.org/sites/default/files/resources/files/Paris Conf Nov2012 proceedings v2.pdf. p 8. Accessed 13 May 2019. ${ }^{67}$ Council of Europe, Respect by Belarus of the Anti-Doping Convention, 12 November 2015. https://rm.coe.int/project-oncompliance-with-commitments-respect-by-belarus-of-the-anti-/168073acb6. p 22. Accessed 30 April 2019.
} 
the approved definition of 'doping' or adhere to the WADA sanctions regime. It said that "the Belarusian authorities are strongly advised to solve this issue as a matter of urgency."

There were also significant concerns about the laboratory used in Belarus for sample analysis. It had been accredited domestically for the purposes of ISO/IEC 17025, which is the international standard applicable to all laboratories that carry out tests and calibrations, ${ }^{69}$ but that accrediting body was not a full member of the International Laboratory Accreditation System as required by WADA's International Standard for Laboratories. ${ }^{70}$ In 2013 , WADA decided not to approve any more laboratories in Europe, and although in 2014 the Belarus laboratory had sought approval for the purposes of the athlete biological passport, this was rejected on the ground that "much remains to be done in sample collection capacity development and consolidation of NADO activities" before WADA could consider any accreditation requests. ${ }^{71}$ Its limited accreditation by the non-compliant national registering body did not extend to a range of banned products including 'threshold' substances, it was not accredited for the detection of erythropoietin or human growth hormone and it was never going to receive accreditation without being awarded 'probationary' status. The NADO's use of a non-accredited laboratory thus "constitutes a non-conformity with the provisions of the (Council of Europe) Convention and an element of non-compliance with the Code" and the Evaluation Team recommended that it should cease sending samples to the Belarus laboratory - which implicitly meant it would start sending them to Russia, which seems to be no solution at all. ${ }^{72}$ It advised that it should put more effort into developing the NADO and laid down a series of steps the laboratory would have to take "in case" it ever gained probationary status. This would culminate in ISO/IEC 17025 accreditation by an international authority rather than the questionable national one. ${ }^{73}$ But this all reinforces the inescapable conclusion that the authorities in Belarus could not have properly tested the paddle athletes' samples without sending them to Russia or, perhaps, Germany. There is no evidence that this happened and it is notable that the CAS Panel did not discuss the actual levels of meldonium

\footnotetext{
68 Ibid., p 23.

${ }^{69}$ As amended in 2017, see International Organization for Standardization, General requirements for the competence of testing and calibration laboratories, 2005. https://www.iso.org/standard/39883.html. Accessed 30 April 2019.

70 WADA, International Standard for Laboratories, 2 June 2016. https://www.wada-

ama.org/en/resources/laboratories/international-standard-for-laboratories-isl. Accessed 30 April 2019.

${ }^{71}$ Council of Europe, Respect by Belarus of the Anti-Doping Convention, 12 November 2015. https://rm.coe.int/project-oncompliance-with-commitments-respect-by-belarus-of-the-anti-/168073acb6. p 25. Accessed 30 April 2019.

72 Radio Free Europe, WADA to Gain Access to Russian Laboratory This Week, 7 January 2019.

https://www.rferl.org/a/world-anti-doping-agency-to-gain-access-to-russian-laboratory-this-week/29696148.html. Accessed 30 April 2019.

${ }^{73}$ Council of Europe, Respect by Belarus of the Anti-Doping Convention, 12 November 2015. https://rm.coe.int/project-oncompliance-with-commitments-respect-by-belarus-of-the-anti-/168073acb6. p 26. Accessed 30 April 2019.
} 
in the samples save to repeat the Belarus authorities' assertion that it was below the threshold. One is entitled to ask 'how did they know?' because the only evidence that the samples were below the threshold was the contents of the BCA's letter to the ICF of 15 June 2016. All that is known for sure is that five of the samples taken from seventeen athletes by the French authorities on 12 April 2016 tested positive for meldonium. Beyond that, the evidence was scant and self-serving in favour of a regime that also made no provision for members of the disciplinary tribunals to be independent of the NADO, where national federations had the power to review tribunals' decisions before they were confirmed and where there was no guaranteed right to a fair hearing, to be represented by counsel or to present evidence as guaranteed by the Convention. ${ }^{74}$ The Evaluation Team warned that the failures "exposes Belarus to concerns that its national anti-doping programme could be used to supervise doping as opposed to deterring and detecting it."75 Belarus replied that it was "working towards cooperation" with UK anti-doping and while this had certainly been the case in 2013, there is no subsequent mention of that relationship on the UKAD website. ${ }^{76}$ Undaunted, the Evaluation Team encouraged it to pursue that relationship and to work more closely with the Monitoring Group and with other countries, in order to help address its concluding concern:

The Belarus national anti-doping programme is too isolated from the anti-doping programme of other major sporting countries. This limits access of the NADA to anti-doping innovation and best practices. (It) has little experience with nonanalytical ADRVs (such as those committed by a coach or sport doctor). ${ }^{77}$

Although it felt the political commitments had been met, the Report concluded that "Belarus has not yet satisfactorily fulfilled the Anti-Doping requirements under the Convention." ${ }^{78}$ It should be noted, however, that as of the 2017 biannual meeting it was not in the list of states deemed non-compliant with the UNESCO Convention. ${ }^{79}$ This raises questions about the utility of the Convention's monitoring arrangements rather than assuaging any concerns about Belarus, and perhaps the next evaluation will address some of those worries; but for the

\footnotetext{
74 lbid., p 32.

75 Ibid., p 36.

76 Ibid., p 38; UKAD, UK Anti-Doping to Work in Partnership with Belarus National Anti-Doping Organisation, 28 May 2013. https://www.ukad.org.uk/news/article/uk-anti-doping-to-work-in-partnership-with-belarus-nado. Accessed 30 April 2019.

77 Council of Europe, Respect by Belarus of the Anti-Doping Convention, 12 November 2015. https://rm.coe.int/project-oncompliance-with-commitments-respect-by-belarus-of-the-anti-/168073acb6. p 37. Accessed 30 April 2019.

78 Ibid., p 38.

79 UNESCO, Conference of Parties to the International Convention against Doping in Sport, 10 November 2017.

http://unesdoc.unesco.org/images/0026/002601/260167E.pdf. Accessed 30 April 2019.
} 
reasons outlined below, future analysis of doping in the country ought to be informed by considerations that go far beyond sport.

\section{Towards a New Perspective on Sport, Doping and Human Rights}

In 2004 the European Union Council, mindful of the rigged elections, the disappearance of political opponents, the endemic corruption and the steady erosion of human rights in the country since Alexander Lukashenka became President in $1994,{ }^{80}$ adopted the first of numerous Common Positions to prevent the passage through the member states of government officials and other persons it deems responsible for human rights abuse and corrupt practices. ${ }^{81}$ This was significant because Lukashenka, who is also the President of the National Olympic Committee, was denied a visa to attend London 2012 as a consequence of those measures. ${ }^{82}$ Thereafter, a host of other Common Positions and Regulations placed further restrictions on, and froze the assets of, people close to his regime.

All this is relevant because "sport under Lukashenka has been hugely important to national prestige" 83 and the relationship is symbiotic. Chelsea FC Chairman Roman Abramovich has invested heavily in its energy and pharmaceutical industries, ${ }^{84}$ Champions League sponsor Gazprom was given 50\% of the national energy supplier between 2007 and 2010 in murky circumstances $^{85}$ and the Kremlin recently depicted the two Presidents playing together in an ice hockey match that their side diplomatically won $16-1,{ }^{86}$ which was a winter coup for Lukashenka given that the countries' relationship is often soured by energy wars.

\footnotetext{
${ }^{80}$ Freedom House, Timeline: Twenty Years of Human Rights Abuses in Belarus, 2014. https://freedomhouse.org/fair-playbeyond-sports/timeline-20-years-human-rights-abuses-belarus. Accessed 30 April 2019. 'Lukashenka' is the Belarusian spelling of the President's name while 'Lukashenko' is the Russian. The former is used throughout, except where necessary in URLS.

${ }^{81}$ Council of the European Union, Council Common Position 2004/661/CFSP Concerning Restrictive Measures against Certain Officials of Belarus, 24 September 2004. https://eur-lex.europa.eu/legalcontent/EN/TXT/PDF/?uri=CELEX:32004E0661\&from=EN; Council of the European Union, Council Common Position 2004/848/CFSP Amending 2004/661/CFSP, 13 December 2004. https://eur-lex.europa.eu/legalcontent/EN/TXT/PDF/?uri=CELEX:32004E0848\&from=EN; Council of the European Union, Council Common Position 2006/276/CFSP Concerning Restrictive Measures against Certain Officials of Belarus, 10 April 2006. https://eurlex.europa.eu/legal-content/EN/TXT/PDF/?uri=CELEX:32006E0276\&from=en. Accessed 30 April 2019.

82 LA Times, Belarus Leader denied entry to Britain for Olympics or Otherwise, 25 July 2012. https://latimesblogs.latimes.com/world_now/2012/07/belarus-president-alexander-Lukashenko-olympic-europevisa.html_. Accessed 30 April 2019.

83 Wilson 2011, p 205.

${ }^{84}$ Belsat, Roman Abramovich to Invest in Belarusian Plant, 12 March 2016. https://belsat.eu/en/news/roman-abramovichto-invest-in-belarusian-plant/. Accessed 13 may 2019

85 Wilson 2011, p 38.

${ }^{86}$ Kremlin, Vladimir Putin and Viktor Lukashenka Took Part in an Ice Hockey Game, 15 February 2019. http://en.kremlin.ru/events/president/news/59845. Accessed 13 May 2019.
} 
One of the Common Positions mentioned above, Decision 2012/36/CFSP, ${ }^{87}$ froze the funds of Yury Chyzh whose business empire had given financial support to the regime in return for lucrative government contracts in the gas and oil industries. Chyzh has held several prominent sporting positions, including Chairman of the Belarus Wrestling Federation and President of Dinamo Minsk Football Club, which enjoys an infamously right-wing fanbase. $\mathrm{He}$ is known as 'Lukashenka's Wallet' ${ }^{\prime 8}$ One of Chyzh's other business interests, TriplePharm, is part of the extensive pharmaceutical industry documented by the Monitoring Group. In Dinamo Minsk v Council ${ }^{89}$ and Chyzh $v$ Council, ${ }^{90}$ the application of the Common Position to the club and to Chyzh personally were annulled because the procedure had violated the EU Charter of Fundamental Rights Article 47 and the principle that "the statement of reasons for an act... must identify not only the legal basis of that measure but also the actual and specific reasons why the Council considers, in the exercise of its discretion, that the measure must be adopted in respect of the person concerned." 91 This has allowed the club to participate in every Europa League season since 2012, but Chyzh is not the only friend of Lukashenka to have extensive sporting interests. "Functionaries of the government, heads of security structures, and business elites from the circle of Lukashenka also serve as heads of sports federations. Chief executives of football clubs are also recruited from the regional political elites and managers of state businesses. Sponsorship of football clubs is carried out by municipalities and regional budgets, by state enterprises and business." 92 Every recent UN Treaty Committee report has noted significant human rights violations by the regime and its associates, ${ }^{93}$ but the relationship between sports and the regime goes beyond individuals in Belarus with their snouts in the trough: a host of international federations are also tucking in contentedly.

Belarus is the only European country to use the death penalty. ${ }^{94}$ It ranks $155^{\text {th }}$ out of 180 countries for press freedom - thus placing it slightly above Iraq but below eSwatini, formerly

\footnotetext{
87 Council of the European Union, Council Decision2012/36/CFSP Amending Council Decision 2010/639/CFSP, 23 January 2012. https://eur-lex.europa.eu/LexUriServ/LexUriServ.do?uri=OJ:L:2012:019:0031:0032:EN:PDF. Accessed 30 April 2019. 88 Vadzim Bylina, Belarusian Ultras and the Regime, 29 January 2013. https://belarusdigest.com/story/belarusian-ultrasand-the-regime/. Accessed 30 April 2019.

89 General Court, T-275/12 Dynamo Minsk v The Council, ECLI:EU:T:2015:747

${ }^{90}$ General Court, T-276/12 Chyzh v The Council, ECLI:EU:T:2015:748.

${ }^{91}$ General Court, T-275/12 Dynamo Minsk v The Council, ECLI:EU:T:2015:747, para. 88

92 Vadzim Bylina, Belarusian Ultras and the Regime, 29 January 2013. https://belarusdigest.com/story/belarusian-ultrasand-the-regime/. Accessed 30 April 2019.

93 United Nations Office of Human Rights, Belarus Homepage, 2018.

https://www.ohchr.org/en/countries/enacaregion/pages/byindex.aspx. Accessed 30 April 2019.

${ }^{94}$ Hugo Bachega, Belarus: The Secret Executions in Europe's 'Last Dictatorship', 15 May 2018.

https://www.bbc.co.uk/news/world-europe-43799280. Accessed 30 April 2019.
} 
Swaziland. ${ }^{95}$ In 2018 the UN Human Rights Council appointed a new special rapporteur for the country and extended her mandate in the light of her predecessor detailing "a purposefully repressive legal framework, aggravated by regularly recurring, centrally planned violent crackdowns on peaceful demonstrators, nongovernmental organizations (NGOs), political opponents, human rights activists and independent media workers." 96 In the late 1990s over thirty political opponents and journalists were murdered or simply disappeared, ${ }^{97}$ and in 2017 after several years of relative calm over 150 journalists and human rights activists were arbitrarily detained, 60 foreign journalists arrested, three bloggers were charged with the criminal offence of "sowing social discord between Russia and Belarus," and new anti-LGBT laws were passed. Human Rights Watch has also noted that "European governments and institutions continue to strengthen relations with Belarus despite a lack of tangible rights improvements" and stated that the country "has a long record of human rights abuses and violations of media freedoms connected with major sports events." This goes some way to explaining why the rise in event-hosting has coincided with a new clampdown on human rights since Lukashenka won the rigged 2015 Presidential election with an improbable 83.4\% of the vote. ${ }^{98}$ In 2017 , this country with a population of under ten million hosted more than seventy world- or Europe-wide events in sports including fencing, skiing, wrestling, judo, track cycling, speedskating, taekwondo, table-tennis and powerlifting. ${ }^{99}$ In 2018 it hosted 75 events in more than thirty sports and in 2019 the number topped 100 for the first time. ${ }^{100}$ In addition to these individual events, Minsk will host the June 2019 European Games, having been awarded them by the European Olympic Committee in $2016 .{ }^{101}$ The EOC has been

\footnotetext{
${ }_{95}$ According to Reporters without Borders, World Press Freedom Index, 2018. https://rsf.org/en/ranking. Accessed 30 April 2019.

96 Viasna, Miklos Haraszti to Present His Last report on Belarus, 31 January 2018. http://spring96.org/en/news/90135. Accessed 30 April 2019.

97 Wilson 2011, p 190.

${ }_{98}$ BBC, Belarus Vote: Lukashenka Re-elected President by a Landslide, 12 October 2015. https://www.bbc.co.uk/news/world-europe-34499387. Accessed 14 May 2019; Human Rights Watch, Belarus: Events of 2017. www.hrw.org/world-report/2018/country-chapters/belarus. Accessed 30 April 2019.

99 Belarusian Telegraph Agency, Belarus to host over 70 international sports events in 2017, 20 December 2016.

https://eng.belta.by/sport/view/belarus-to-host-over-70-international-sports-events-in-2017-97361-2016/. Accessed 30 April 2019.

100 Sports Events to Be Held in Belarus in 2018. http://india.mfa.gov.by/uploademb/india/2017/sports_calendar_2018.pdf. Accessed 30 April 2019; Belarusian Telegraph Agency, Belarus to Host 100 Sporting Events in 2019, 18 December 2018. https://eng.belta.by/sport/view/belarus-to-host-100-international-sport-events-in-2019-117442-2018/. Accessed 30 April 2019.

101 James Ellingworth, Belarusian capital Minsk Awarded 2019 European Games, 21 October 2016.

https://apnews.com/4bbf3e727ec7425b9c979c04d16cbac5. Accessed 30 April 2019; Denmark and Norway voted against the decision, while Germany and Great Britain were among five who abstained: Michael Pavitt, Germany to Send Team to Minsk 2019 After Opting Against Boycott Over Human Rights Concerns, 18 February 2019. https://www.insidethegames.biz/articles/1075721/germany-to-send-team-to-minsk-2019-after-opting-against-boycottover-human-rights-concerns. Accessed 30 April 2019.
} 
assured that the media will have "free access" to the Games, ${ }^{102}$ but in a country where journalists are regularly imprisoned, the President has a personal fortune of over $\$ 11$ billion $^{103}$ and political opponents disappear, that rather misses the point.

\section{Conclusion: Taking Rights Seriously?}

There are legitimate arguments that sports' engagement in countries with despotic regimes can perhaps be a force for good, ${ }^{104}$ and there is some evidence of the EOC asking awkward questions as the Games approach. ${ }^{105}$ But the President has also said that Belarus athletes are "obliged" to do well at the competition and that children, the elderly and those with disabilities should be "invited, not forced to attend...to ensure the stands are full." Concerns about whether Belarus has a laboratory capable of testing for meldonium or whether the sports media can accurately report who wins the beach soccer are irrelevant if they are not placed in this wider context. Similarly, if Belarus has improved its anti-doping procedures one might reasonably expect evidence of this in the European Games, but one also worries about how national athletes will respond to pressure from a populist despot who says that "the people are tired of waiting for results." 106 In both respects, whether international actors have the inclination, the resources and the opportunity to closely enquire into what their new best friends in Minsk are up to remains to be seen, but one should not expect too much because the overtures of sports organisations have not come with strings attached. WADA, the Convention Monitoring Group and those countries who have signed bilateral arrangements might be able to influence the anti-doping landscape, while perhaps the news media, event sponsors and those National Olympic Committees who considered boycotting Minsk 2019 can work behind the scenes on the wider human rights issues, but the two should operate in tandem. Human rights groups and academics also have a role to play.

To conclude by returning to the case, the ICF was probably trying to do the right thing but acted hastily when confronted by a national federation and a national anti-doping agency which inspired little confidence. If one accepts Prof Kalvin's assertion that meldonium "is

\footnotetext{
102 Ibid.

103 Wilson 2011, p 243.

104 Turley 2016.

105 Dan Palmer, Kocijancic Meets With Belarus Prime Minister as Minsk 2019 Looms Closer, 8 February 2019. https://www.insidethegames.biz/articles/1075286/kocijancic-meets-with-belarus-prime-minister-as-minsk-2019-loomscloser. Accessed 30 April 2019.

106 James Diamond, Belarus President Piles Pressure on Home Athletes Before Minsk 2019 European Games, 5 January 2019. https://www.insidethegames.biz/articles/1073903/belarus-president-piles-pressure-on-home-athletes-beforeminsk-2019-european-games. Accessed 13 May 2019.
} 
very safe and has very mild side-effects, there were less (sic) than 90 serious events, $" 107$ one is once again left wondering why it is banned at all and it is possible that meldonium will be allowed out-of-competition in a few short years. If that happens the decision in $B C A v I C F$ will still be important, for it sheds light on a particularly grubby aspect of sport in a country that too often flies under the radar and provides a window on a world far beyond anti-doping. The kayakers and canoeists of Belarus, and the coach with the bag of meldonium, have done the sport and human rights community a considerable service.

\section{References}

Hanstad D, Houlihan B (2015) Strengthening Global Anti-Doping Policy Through Bilateral Collaboration: the Example of Norway and China. International Journal of Sport Policy and Politics 7(Issue 4) 587-604.

Hertogh M, Kurkchiyan M (2016) 'When Politics Come Into Play, Law is No Longer Law': Images of Collective Legal Consciousness in the UK, Poland and Bulgaria. International Journal of Law in Context 12 (Issue 4) 404-419.

Turley T (2016) When the 'Escape' Ends. Responsibility of the IOC and FIFA at the Intersection of Sport Law and Human Rights. Notre Dame Journal of International and Comparative Law 6 (Issue 1)145-165.

Wilson A (2011) Belarus: The Last European Dictatorship, Yale University Press. 